\title{
Gender Perspective to Vedic Education: Current Practices in Nepal
}

\author{
Rajendra Raj Timilsina
}

\begin{abstract}
Vedic civilization has seen changes in its history- from Satya Yug to current Kali Yug. There were equal rights and duties of both men and women at the beginning. Interpretations of Veda, brought out of the Puranas and externalities made the status unequal. Sanatan Dharma, which is still mainstream of Hinduism, has been challenged by reformist Arya Samaj. As a result, there are interpretive differences as well as practices. Such differences can be seen in contemporary Nepal for the last 130 years. Continuing the differences, classicism has been reviving in the education. This revival also commenced with the same dualism. In this qualitative approach of exploration, two different gurukuls of girls have been observed and analyzed from the field for the purpose of exploring the recent practices. The observation was based on respective scriptures as well as experts' interviews. These data have analyzed the confronting practices on gender in Veda and rooted ideas in contemporary Nepal.

Keywords: arya samaj, female, Nepali gurukuls, sanatan dharma, Veda, vedic.
\end{abstract}

\section{Introduction}

Some authors critique Vedic or Hindu society as discriminatory against female. Among them, Magsaysay award winner Christian author Arole (1998) wrote in the brand of UNICEF in 1998: "Women were given the position of sudras, and therefore they were considered inferior. They were also denied the right to study the Vedas." Kaundinnyana (2007) challenged the idea of Hindu women's subordinate position focusing on "Vedic Dharmashastra 
(theosophy) and property rights of women". He has counter attacked to such critical conclusions. Meanwhile, the gender construction in Vedic society (Adhikari, 2014) which found there was no significant discrimination as it has been blamed. Total 81.3 percent Hindu population (CBS, 2011) has been rooted in Vedic knowledge originally. Foreign scholars have often analyzed the topic of discrimination. However, accuracy of such blaming or clarification has been raised questions as well. This paper intends to explore ontology of the topic on the basis of contemporary ground reality. In so doing, Vedic girls' schools have been observed comparatively in triangulating the theories and previous data relating to the Nepali education.

History of general school education in Nepal shows that there was only 4.4 percent (3242) girls' enrolment in 1955 as the Bureau of Publication (BoP, 1956) had found. Since then, global influence has pushed up girls' enrolment in school education is increasing in recent years in Nepal. If we look at the ratio of boys and girls in School Leaving Certificate (SLC) examinations in recent years, the data shows number of girls is higher than boys. Similarly, Vedic education also is attracting the number of girls compared to boys as department of education data shows. Girls have been engaged in studying Vedas in co-education model Veda Vidyashrams. Separate gurukuls for girls also have been established in some parts of the country. Number of Vedic gurukul schools and Veda Vidyashram has been increased in recent decade in Nepal. As informed from authorities that the number has reached nearby 200. Department of education states that 98 such schools are in connection with the government of Nepal (DoE, 2014).

The western model of education system was introduced in 1972 (2028 B. S.) in the name of new education (naya shikshya) which almost ignored traditional schools and they were known as "Bhasha Pathshala". People were attracted to new schools. As a result, gurukuls run by gurus in different temples went into crises. Some "Pathshala" restructured as Sanskrit general schools. Such schools have been still running as modern Sanskrit school with scarce of students. These all were applied on the ground of the report submitted by national education planning commission, 1956. Oregon professor Hugh B. Wood was educational advisor and he was influenced from 


\section{6| Rajendra Raj Timilsina}

T. B. Macaulay minutes of 1835 for restructuring Indian education which totally ignores local cosmology. The British colony's Lord Macaulay had propounded his notion: "We must at present do our best to form a class of persons Indian in blood having colour and English in taste, opinions in morals and in intellect." Similarly, the Wood commission had portrayed Nepal as "the country is in a state of utter barbarism and ignorance" (BoP, 1956, p. 63). Such notion had ignored the Vedic education system.

Today, on the one hand, Sanskrit secondary schools have made inclusive and number remains nearly a dozen. On the other, gurukuls are reviving for different target groups like: only for boys, only for girls and for the both. This changed situation shows that Nepali communities have been accepting the re-emerging concept of classicism because the Vedic schools- Veda Vidyashrams and Gurukuls are initiated mainly from the corners of the peoples. The diagram speaks the incremental figure of the classic education below:

Figure 1: Incremental Figure of Vedic Schools in Nepal:

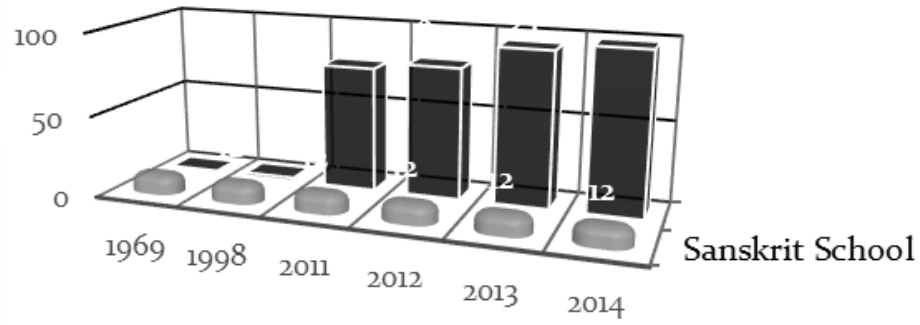

\begin{tabular}{|l|c|c|c|c|c|c|}
\cline { 2 - 8 } & 1969 & 1998 & 2011 & 2012 & 2013 & 2014 \\
\hline a Sanskrit School & 12 & 12 & 12 & 12 & 12 & 12 \\
\hline - Ved Vidyalaya & 1 & 2 & 76 & 80 & 94 & 98 \\
\hline
\end{tabular}

Source: DoE, 2011, 2012, 2013 \& 2014)

First formal gurukul was founded by Nepal government in 1969 (CERID, 2007). This was established because Sanskrit schools could not produce appropriate human resources for rites and ritual of the Hindu dominant Nepal. However, there was no another Veda Vidyalaya till 1998. However, Devghat of Chitwan-Nawalparasi and 
Chisakhola of Pokhara had initiated for the Veda school from nongovernmental efforts. Such data do not reflect informal gurukuls running in different places of the country which have not been registered in formal bodies. Line of the diagram was gone up after 2006 movement for republicanism in the country. On the other side, number of modern Sanskrit schools have been remained the same. Nearly 150 such gurukuls have been registered so far in different districts in Nepal. There is no data for the gurukul which are still to be ministering to the national education system.

Among the Gurukuls, three head teachers found female. Some of the gurukuls have been running only for girls. Such girls' schools have dualist perspectives of Veda education and Vedic one. These schools reflect controversy of jurisdiction of girls to the Veda as male study. This paper explores perspectives between Muktinath Gurukulam and Gargi Kanya Gurukul with philosophical foundations. However, we cannot see schools for girls where they can practice Veda learning as boys do. Nepal's neighbor India have number of schools for girls who can practice and perform Vedic hymns with hands' movement classically in public places (www.news.biharprabha. com/2016/08/700-school-girls-chant-vedic-hymns/). Vedic Hymns are known to boost one's mental energy and are an important aspect of Hindu spirituality (Bihar Prabha, 16 Aug, 2016). In Nepal, either latent or hidden hesitations can be felt among girls who intend to chant the hymns. Juxtaposed, Gargi gurukul girls chant the hymns like the boys without any hesitation. The school has been running with financial and academic contribution of social philanthropists. The first batch of girls have reached to grade six from grade one. Of girls now reached to grade six from one. Now, the girls have completed Rudree perfectly as observed. Female centric such Vedic practices have been reemerged since last one decade nearly if we calculate from Muktinath Kanya Gurukulam.

\section{Defining Key Terminologies}

"Rudree" is concise form of Veda where gods are prayed for success of the devotees. Mantras of Rudree are repeated in Yajur and Rig Veda. The mantras used while performing different worships in the Vedic rituals. Thus, Rudree is foundation for Veda learning. It has been said that one can complete all Veda who can complete 


\section{8| Rajendra Raj Timilsina}

the Rudree with due process. Consequently, Veda Vidyashram and Vedic gurukuls emphasize on teaching Rudree as foundation of chanting, proper pronunciation and rote learning. Rudree is recited while "Rudrabhishek" is performed as Maharshi Mahesh Yogi's Transcendental Meditation course done in praying Lord Shiva specially.

Dwija is another term used in this paper which is much used in Vedic or Hindu society. Dwija means twice born castes they areBrahman, Chhetriya, Baishya. They born naturally at the first and they again got rebirth through Upanayan (Brtabandha) ritual for starting schooling. "Bratabnandha" is a ritual which begins schooling. Michaels (2004) defined it as "initiation". "One is indeed Hindu by birth, but not only by natural birth", he says: For men, the second authentic birth is being born in the Veda and out of Veda, in the holy knowledge (p. 71-72). Another term has been used in the paper is- "Sudra". This is fourth caste in caste hierarchy. Service to other three (Dwija) is duty, according to the caste system. Now, they are known as "Dalit". Manusmriti, Hindu jurisprudence says the fourth has one birth only and there is no fifth caste (Jodkha, 2012 , p. 72). Theories of such Varna origin (Khatry, 2060 B. S.) was on the basis of professional skills where members of same family could chose different profession and feelings of untouchability was not developed during Vedic period. The system or practice of untouchability was twisted form which does not exist in the Vedic system. It was in practice as per people's choice of works and skills. Another term is: Gayatrimantra. Mani (1975) defined this as glorious Vedic mantra:

This mantra has 24 letters. There are 19 categories of movable and immovable things in this world and to this if the five elements are added the number 24 is obtained. That is why the Gayatri has got 24 letters.

If one recites gayatri once she/he will be free from all sins done on one whole day or will be washed away (p. 288). This is a hymn which has been practice daily by Dwija. This is a prayer of Sun. This daily practice has been achieved authority after Bratabandha. However, in recent years, the mantra has been popular for all by media though listening and practicing with senses might be felt different. 


\section{Purpose and methods}

Purpose of the write up is to search the status of women in Vedic/ Hindu society. Hermeneutical analysis was based from India as well Nepal and field observation have conducted in Nepal. Finding answers of whether the Hindu women's position is like "sudras", analyzing differences of the theoretical and practical aspects among Vedic societies and rights of female to Veda and Vedic practices are main objectives of this paper.

In this qualitative approach, participatory observation, interview and hermeneutic methods have been applied in exploring the status of preaching and practicing of the education for girls/women education in Hindu society. Gargi Kanya Gurukul, Kathmandu, Muktinath Kanya Gurukulam, Bhaktapur and Pokhara Chisakhola Veda Vidyashram were selected as main fields for the observation. Similarly, Subhadra Nepal, Principal of Gargi Kanya Gurukul; Swami Kamalanayanacharya, founder of Muktinath Kanya Gurukulam and Professor Deergha Raj Ghimire were interviewed as key informant participants of the exploration in search of Vedic perspective/s theoretically and their pragmatism with the eye of gender. Likewise, Vedic literatures and journals were reviewed and reflective journals were also used from the fields. Sage Jaimini's Poorva Mimamsa (Vedic Philosophy on ritual and rights) and Dayananda Saraswati's Satyartha Prakash (Arya Samaj's interpretation on Vedic rights and duties) are taken as bipolar foundations of epistemic interpretive mainly.

\section{Ontological changes}

Taking myself as a participant, I have been recalling this changing context of Vedic education in the country for last three decades. There were my six sisters and one elder brother among my sibling in the school age. My father taught Veda chanting with signs of hands how a rote to me and my brother every morning after the age of seven. However, all my six sisters had no right to practice such chanting. My mother used to practice chanting several verses of Geeta, Ramayana, Mahabharata, Chandi (prayers to goddess Devi) except chanting and practicing mantras of Veda. Similar teaching was in practice for the sisters. Other Dwija students were also used to come 


\section{0| Rajendra Raj Timilsina}

to learn the skill of Veda chanting my father's Ashram. There were no female students. I was admitted at Sanskrit High School where I completed school education with specializing Sanskrit language and Rituals in 1989. The school was run as National Education System Plan (NESP), 1971 which had provided guidelines for three kinds of high school (class 6-10): general, vocational, and Sanskrit (Weinberg, 2013). There was only one Veda Vidyashram in Pashupati area in Kathmandu for practical vocational stream and some schools were running in different parts of the country as the general modern Sanskrit school.

On the other, my father's Ashram modified as government Veda Vidyashram and curriculum made formalized from 1997. Female were allowed to study Sanskrit, Sanskrit grammar, and other related subjects. Two female completed school education from the school. They know very well about the Veda chanting while their male classmates practice at the Ashram. But, they were not allowed to chant the hymns. However, one female student completed two chapters of Rudree as same as male chant because she informed that she got right to chant Veda form Yogi Narahari Nath while she was child. Likewise, my brother's son got married and my father has been teaching Veda (Rudree) to her.

\section{Women's Access to Veda: Interpretive Contradictions}

Muktinath Kanya Gurukulam has produced nearly a dozen of girls who have established as Pauranic story teller who have been leading Yagyas related to Purana in different parts of Nepal. However, they cannot recite the mantras of Veda. I interviewed Swami Kamalanayanacharya, founder of the gurukul- why the girls were not taught Veda? He has logic about rights and duties of male and female. He links gender perspectives to the different organs of human body such as- eye, teeth, ear and nose. As the one organ cannot perform other organ's role, similar separate role has been remaining with male and female, he elaborated. Further, there is biological aspects which directly affects Vedic Yagyas because women have no rite of Bratatabandha (Upanayans) which commences Veda schooling, they do not wear yagyopabit (sacred thread) in one's body, they do not maintain the process of shikhabandhan (braid/crest over head) and most importantly female has main biological complexity for Vedic 
yagya has been taken as menstruation. Abdominal or stomach pain can hamper the concentration which is essential for Veda and Vedic Karma can affect during the period. Likewise, women has duty of procreation and pregnancy and giving birth of child also disturbs the Vedic recitation with signs of hands and performing yagya, according to the interpretation. So, Muktinath Kanya Gurukulam chosen Puranic education than Veda to the girls, the Swami informed.

Similarly, professor emeritus Deergha Raj Ghimire is one of the main Vedic scholars who have been involved in decisive interpretations for Vedic rites and ritual in Nepal. Priests of Pashupatinath, largest Hindu temple of the world and Vedic scholar also consult Ghimire for such crucial condition. I asked Ghimire about rights of the women in Veda learning because there were separate practices between Gargi Kanya Gurukul and Muktinath Kanya Gurukulam. Ghimire differentiated the dualist model of contemporary Hinduism as Sanatan Vedic (conventional) and Arya Samaj (a slight reformist). According to this dualism, Sanatan Hindu Dharma follows the traditional way as Muktinath Kany aGurukul has been following. On the other hand, Gargi Kanya Gurukul which teaches Veda girls is representative of Arya Samajee campaign of equality. The Gargi girls now studying at grade Six can chant Vedic mantras as boys of other gurukuls can. They go Pashupatinath temple with their head teacher Subhadra Nepal and recite Rudree in different occasions. The school has vision that the girls will be performing Vedic practices as do male.

However, Ghimire questioned me- "Does the society accept female as priest?, Can you invite women as priest for rites and ritual? Do you see any female priest surrounding Pashupatinath temple, who are chanting mantra?" He said there is no tradition of women priest in India as well.

There are two branches of Vedic Philosophy- Poorva Mimasmsa (Dharma Sootra) and Uttara Mimamsa (Brahma Sootra). Poorva Mimamsa is for Karmakanda (for practicing rituals) and Uttara Mimamsa is for Gyanakanda (for philosophical interpretation of Veda) generally (Leaman, 2004). However, Poorva Mimamsa includes meaning making process and interpretation of knowledge. Shankaracharya had used Jaimini's Sootra (Poorva Mimamsa) for 


\section{2| Rajendra Raj Timilsina}

Vedantic interpretation of Brahmasootra (Musalgaonker, 2004). This analysis takes Poorva Mimmamsa is Laws of interpretation for daily life as well (p. 9). Ghimire takes this Poorva Mimasa and Manusmriti as law of Hinduism. "Women should learn Veda but after marriage", he says: there is no provision of Bratabandha for girls as boys do. He substantiates a proverb from Poorva Mimamsa in Sanskrit- पाणि ग्रहणातु सहत्वम् कर्मसु । (pani grahanattu sahatwam karmasu). [Means: Holding hands of bride by groom during marriage ceremony itself starts Veda learning and Vedic practice]. In the ceremony the bride should chant Vedic mantras while performing sacrifice to fire (hawan). This process has been taken as Bratabandha in Ghimire's point of view. After Bratabandha, the Dwija (twice born casts which get rebirth after Btratabandha) should perform Sandhyopasandaily ritual at least twice a day. Sandhyopasan is a foundation of Vedic education (Timilsina, 2015). Sandhyopasan practice similar to men cannot be found among female though most faithful Hindu women do according to Puranic way of pray daily practice.

In contrasting Ghimire, another renowned Vedic scholar Shiva Raj Acharya Kaundinnyayanah argues that women have right to Bratabandha ritual and studying Veda in accordance to different theosophical literatures of Hinduism. Kaundinnyayanh (2009) clearly says women (stri) has right to perform Sandhyopasan. While doing Sandhyopasan, making knot is possible by managing hair by women is equal to making braid knot by male (p. 127). Male are used to manage braid but female keep long hair all the time. So, he described women's act citing different Vedic sources on Shikha. Similarly, his son and a member of his swadhyayashala (a home for practicing Vedic integrity), Amod Bardhan Kaundinnyana (2007) have also follows his father's argument and analyzes as women have equal right and duties on Vedic learning and practices of women from Bratabandha rite.

\section{Discussion}

Hinduism faced several attacks from Muslim, Christian and even Buddhism in the past. Firstly, India was conquered by Muslim imperialists who also had entered Nepal in 1349. Samsuddin Illiyas, Sultan of Bengal had attacked in Kathmandu and destroyed number of religious heritages including Pashupatinath temple (Baidya, 
2001). Kolkata was one of the major entry points from sea for invaders and Samsuddinn was came Kathmandu from Kolkata to attack non-Muslims.

Secondly, according to Musalgaonker (2004), Buddhists had terrorized against Hindus in the name of science theory of Buddha and Hindus were compel to flee away from conversion tyranny. In this account, Swami Saber also flee to cave. In the cave time, Saber wrote commentary over Jaimini's Mimamsa philosophy "Dharma Sootra" (p. 20) which was known as "Saberbhashyam". Musalgaonker has discussed Sabar's "Saberbhashyam" in Hindi (2004).

Thirdly, colonial British attacked Hinduism through education through Lord Macaulay's minutes which introduced English model education in India. Macaulay has been criticized for unrealistic education in the county where all local narratives have been converting to Christianity (http://www.columbia.edu/itc/mealac/ pritchett/00generallinks/macaulay/txt_minute_education_1835. html). Similarly, in Nepal, Wood(USA) introduced similar education in Nepal which totally ignored local knowledge system. Wood also been criticized for not valuing people's knowledge and practice of different aspects of social, cultural, economic and political wellbeing (Parajuli, 2013). The Christian ruler and experts undertook whole education towards as homogeneity as Anglo Saxon had been following. Indigenous knowledge system not valued to promote English as expansion of westernization as well as earning money. Still, they have been earning huge chunk of money in one's GDP from "language export" where they send teachers, books and CDs as well different types of language testing. They brought their modernization and reforms in India and entered in Nepal from India. These can be taken as non-Hindu attacks to Hinduism which had affected Vedic teaching-learning processes and obviously, gender perspective had also hampered. Let us talk about Hindu's own debates on following paragraphs which link to the female education worldviews and Veda practices can be analyzed.

Connecting gender perspective of Hinduism, we can see two school of thoughts of female education in the oldest religion of the world, the Vedic Dharma and these two represent the two gurukuls of 


\section{4| Rajendra Raj Timilsina}

Kathmandu valley as mentioned above. Muktinath Kanya Gurukulam represents Sanatan Dharma that is known as eternal way beyond human origins. No one started this Dharma but it was existed while human evolved in the earth, as the Dharma defines as sanatan. This is mainstream of Vedic dharma. It applies all scriptures from Vedas to Ramayana, Mahabharata and Puranas as interpretation of Vedas. This has been known as rigid which follows Poorva Mimamsa as laws of interpretation as Musalgaonker observes (p. 9). This is orthodox school (Leaman, 2004), which interprets proper yagya (ritualistic sacrifice) reserves space in heaven for the performer. Leaman (2004) further says:

Purva Mimamsa Sutra by Jaimini (400 B. C.) is a scholastic piece of work and confines itself almost entirely to the interpretation of the Vedas. This school of philosophy is interested mainly in inquiring into the nature of Dharma (right action), and since it accepts the Veda to be both infallible and the sole authority on Dharma, one can call it a fairly orthodox school. (p. 249)

However, the time- "400 B. C." cannot be accurate calculation for Jaimini because current year of Vedic calendar is 5082 according to Vedic astrology "Vedangajyotisham" (Kaundunnyanah, 2005 \& 2009). Vedic era has been counted for last 5082 years. Sabar's era might be B. C. 400 because there was Buddhists whim of conversion and went cave writing commentary on Jaimini'ssutra (Formula) as Musalgaonker claimed. Anyway, Sanatan Dharma follower Vedic scholars apply the Jaimini's formula in daily life. Thus, Professor Ghimire recites the formula which elaborates rights and duties of women according to Vedic perspective. Lady can/should learn, chant and practice hymns of Veda from the marriage ceremony when the groom takes her hands and they worship fire and sacrifice grains and butter. During that hawan, the bride compulsorily should pronounce Vedic mantras before the fire-god (Agni Dev).

Vedic laws found changes according to era wise interpretive scriptures. There was no menstruation till Satya Yug and concept of purity and impurity of women was not there, professor Ghimire said, there was no biological menstruation of women because procreation was done through mentally that was called- maanas prajaa who were 
created doing yoga. Maanas means birth by thinking. "Menstruation started only since Treta Yug", he confirmed. According to Puranas, creator Brahma had created 17 maanas putras who were created from different organs: ear, eye, mouth, nose and so on. This history shows that practice of Vedic (Sanatan) Dharma had been developed further according to different era as Purani cscriptures were also written and interpreted. This main stream interprets the practices as Manusmriti as latest Hindu law of rituals and daily practices. Thus, anti manusmriti movement has been reportedly running by women and Dalits from India and now, in Nepal as well, as taking the law as discriminatory to them. This law (Manusmriti also interprets upanayan (bratabandha) of women is her marriage: वैवाहिको विधिस्त्रीणाम् औपनएनिक: स्मृतः (Vaivahiko vidhistrinam auopanaenikah Smritah) Ghimire added another citation in addition to Purba Mimamsa. Thus, it starts from the Yagya mandap where marriage ceremony is held.

On the other hand, Arya Samaj (Society of Nobles), an organization established in 1875 in India, for reforming Hindu society emphasizes to abolish the hereditary caste or varna systems and aims to uplift the mass of the people through education. Swami Dayananda Saraswati was the founder of the movement who wrote reformist law of Vedic Dharma Satyartha Prakash (1875), which means: "The light of meaning of truth."Sanatana Hindu dharma worships gods, idols and reincarnation (avatar). However, Arya Samajees reject worshiping idols, advocate for all human beings are equal and all should have equal opportunity (Dayananda Saraswati, 2008, pp. 250-256). Similarly, it advocates for empower of women as Vedas described. The all have the same right of hawan (fire altar) of yagyas all can recite mantras of Veda. Dayananda Saraswati has interpreted all Vedic mantras and provisions of manu smriti in accordance with his worldview of equality.

The reformist sect cites Atharva Veda's mantra number 11.5.18 and 11.6.1 mainly for authority of women for Veda learning and chanting as men do. Arya Samaj followers are in Nepal who suggests girls go to study in India reformist schools. Gargi Girls' Gurukul found influenced from that sect and principal of the gurukul was also studied in Arya Samajee gurukul in India. Either Sanatanee or Arya Samajee, this revival of gurukul has brought happiness to women who learnt Vedic education somehow. Pushpa Pokhrel is one of them 
who knows there was no discrimination in learning and teaching in gurukuls in early Vedic period. She says and Non-Hindu attacks had discarded the equal education at the Vedic history (Pokhrel, 2012):

After Vedic era and in the Smriti period, there were created complexities for women as external attacks started to Hindu Dharma. As a result, women and children were being first victim. Going out from home was impossible to them and they became unable to move outside. After Smriti era, modern era started where boys were allowed to study Veda in gurukuls after their Upanayan. Girls were deprived. Later, gradually, female started studying Vedic meaning though they were not allowed Veda as male chant with loud vocal and signs of hands. They helped the members of the family who were teaching at gurukuls. Female became happy with helping heart, mind and works. Time has been changing and again women have came to the turning point. They are getting chances to study at the gurukuls. Gargi Kanya Gurukul and Muktinath Kanya Gurukulam are only for girls and other various gurukuls have been teaching girls and some of the schools have recruited female teachers as well. This is golden opportunity to peruse the knowledge of Vedic tradition. (p. 40)

This shows the revival of Vedic gurukul education in Nepal. Behind this revival there were several revolts by women in different times in different places. Female who left their home in search for their own inner soul are exemplary for the scholars. According to Swami Prapannacharya (2013)Yogeshwori Anjana Devi' (1991-1981) was originally from Nepali Rai community renowned for her devotion and contribution. So, Kalyan, a religious magazine of India had named her as "Nepali Meera". Originally, Meera Bai was a 16thcentury Hindu mystic poet and devotee of Krishna in India and Yogini Anjana named as "Nepali Meera". Similarly, Yogmaya Neupane (2002) had also contributed to reform Vedic society for justice. It was very impossible to general women for revolt with inequality in family and society in every society of the world. However some of the Nepali ladies have established the history.

Yogmaya Nepane, born 150 years ago (approximately), of Bhojpur district had revolted against the unjust practices of the society where 
the priests were used to cheat to the society in the name of gods. Before sacrificing with several followers, she had written poem verses. The Verses:

यौटा घर श्राद्ध खाई अर्का घरमा आँटे,

ग्रहहरु बिन्ति गई्छ पूरोहितले ढाँटे ।

विद्या लिनु ब्राह्मणले व्यासासनका धनी,

बनियाँका काममा लागे उत्तम मणि पनि ।

Meaning:

A priest goes to more than one client for ancestral ritual,

However, they have been working as vender, which are best in society.

Brahman should learn who are working as real agent of vender who had written the Veda in the past, Planets have been telling that the priests lied (p. 84).

Connecting to Anthropology of education, there are four foundations of education: historical, philosophical, sociological and psychological. Gender perspective of Veda and Vedic education obviously connects to all foundations. Education system was introduced by Vedic sages in the world (Majumdar (2008) cited in Adhikari (2014). Vedic hymns were sources of concepts of soul and super souls and their relations. Education system was propounded for learning and teaching the life world and realization of problems, liberation from inhuman traps and other qualifications (p. 86). This can be viewed as historical as well philosophical foundation of the education contextually. Vedic naturalism was there in the era of Vedic civilization. There was gurukul schooling system. Girls were used to go gurukuls so that Biswambhara, Apala, Aatreyi, Ghosha other female scholars who also discovered the several Vedic mantras. Nearly two dozen of the female scholars among other male who are known as propagator and distributers of the Vedic knowledge system, as Adhikari describes.

Historically, Separate gurukul for girls could not promote female education at that time so that the tradition was lacked. In view of Mishra (2003) special attention had not been given for female education because of absence of co-ed system (p. 148). There were separate schools for boys and girls because of concept of 'far from possible affection' and ideals of Brahmacharya(chastity). This has been emphasized by Arya Samaj as well. In contemporary Nepali 


\section{8| Rajendra Raj Timilsina}

gurukuls run by public have co-ed and inclusion for all where Brahman, ethnics and Dalits have been studying Veda and Vedic moral education in same rooms which have been analyzed as NeoSanskritization (Timilsina, 2013) in the caste based societies.

Sociological and psychological turns also have been changing as changed technology, forms of war, forms of properties and powers. Structural-functional practices found dominant except very few radical revolt by some ladies who later renowned as scholar and Yogini. Structuralism and so called modernism has been challenged which could not established real justice and equity in societies in the world. Post modernism, post development and postpost development has been already felt by some of the scholars. Sociological foundation has been always prevailing in the societies. Male were warrior, they had not to face menstruation, no pain of pregnancy, and real feeling of motherhood and childcare. Finally, preserving the procreation process of the "man" is another. This procreation process and wars disturbed female in remaining political power.

Sense of classicism has been reviving globally whether the place might be Nepal or India or elsewhere in the world. So far connection of this paper, Sanskrit is main gateway to original Veda and Vedic textures. Modern Sanskrit school, Gurukul and Veda Vidyashram contribute to enhance Sanskrit skills and the language push to get taste of Vedic literature. Indian origin physicist who later turn to Vedic meditation as he coined as "transcendental meditation", Maharshi Mahesh Yogi had announced: "Nepal can lead the world" in his address in Kathmandu mass meeting in 1970s. He had expected much and substantiated that Nepal is a centre of spirituality. However, he was announcing this at that juncture Nepal was adopting western model of development and modernization as status of Nepali knowledge as "utter barbarism"

Nearly 58 years after, in 2013, India had formed Second Sanskrit Commission in promoting the Vedic knowledge system which has submitted its report recently on reform of education system of the country. The commission has proposed a school board of Sanskrit education and a Sanskrit university in every state with four language policy in every stream of education (Chopra, 2015). Similarly, the 
commission has recommended the introduction of a compulsory Sanskrit paper in all science and technology institutes as well as the inclusion of Sanskrit teachers in their faculties. Further, underlining the importance of scientific achievements in ancient India, the second Sanskrit Commission has recommended a host of measures to revive interest in the language, including the establishment of special laboratories where scientists and scholars can work together to corroborate ancient beliefs such as the power of Vedic sacrifices to induce rainfall and the healing qualities of sacrificial ashes as Chopra informed.

Indian scholars have been re-searching their ownness in knowledge system. They realizing now that Vedic practice of swadhyaya which have complete philosophy of personal development though it has two fold meaning: "self-study" and "study of self" (study of one's inner self) (Grover, 2015). According to this analysis, "swadhyaya" is main mantra of India education and ignoring the mantra, India is paying the price heavily. Such foundations of Vedic education have several life management foundations which have self-healing, selfcontrol and self-treatment system by one's one. Such educational practices have even made alternative medication to the patients of different diseases (Timilsina, 2015) as found in Asian, European and American health related studies reflected. Such studies have acknowledged the value of the Vedic knowledge construction and education.

Sanskrit has been searched when the Nepali feel its necessity while they know there is something which engages people because they used to follow their religious as well as ancestral rites. Verses and hymns are in the medium so that numbers of interested persons are increased as respective scholars informed. Some of the gurus have been running private tuition classes for the people. Such people have been influenced from Indian news items which inform that India have been reviving ancient knowledge for linking modern science. Several famous private boarding schools also have added Sanskrit subject to promote moral education which brings the pupil to moral verses of Sanskrit and one's ritualistic values. There is historical nostalgia of peace as Khatry (2060 B. S.) described: Character building was main objective of the education in ancient period which makes the people self-sustained, accountable to society, can preserve ancient 


\section{0| Rajendra Raj Timilsina}

culture, female education were also heart touching (p. 143-144). Morality and character building is virtue of gurukul education as the gurus say. Vishuddha Dev (2059 B. S.) defined character in his Characterology as balancing of these three: willpower, knowledge power and working power. Yoga and meditation builds character as Veda and Vedic scriptures have state. According to Vishuddha Dev, People should back to control thinking by human instead of controlling human by thinking. They should come back to human originality which in natural (Bhattarai, 2016).

Vedic knowledge has not been ignored in the world though modernization has been affecting it. Actually, Nepal was leaving Vedic education while western universities were establishing Vedic based faculties and departments in the name of Hindu, Sanskrit and Oriental or Asian or South Asian studies. US migrated Nepali Professor Nanda Shrestha's work entitled "Becoming a development category" which analyzes western model of development which made local way of life were backward (Willis, 2005, p. 193). Cultural globalization and cultural homogenization as well as western consumption practices as neo-colonialism:

In 1951, after a change of ruler in Nepal, western-funded development projects were introduced. The concept of development in Nepali is bikas. Shrestha describes how people were seduced with western -funded bikasas being good and of value, and everything else which was associated with existing way of life as taking inferior. This included forms of traditional medicine, manual labor, language and education. Bikas was regarded as desirable because it bought paved roads, school buildings and technology, even though hunger persisted and self-reliance and autonomy declined. Shreshtha interprets this process as a form of colonialism, where European and American ideas and cultures are presented as being superior to indigenous ways of life. (Willis, 2005, p. 29)

Developed countries have been preserving ancient knowledge system. Recently, in 2016, a Nepali scholar, Diwakar Acharya has been appointed the Spalding Professor of Eastern Religions and Ethics Department at Oxford University in the United Kingdom 
as media spread the news. Western funded advocacy campaign has been affecting traditional knowledge system. Amodbardhan Kaundinnyanah who wrote on Vedic Gender (in Nepali) asked counter question me: "Even male do no study the Vedic idea, how we can expect from female in this scarce situation of foreign effects?" This question has been raised at that point when donor community has been contributing to School Sector Reform Plan (SSRP) and the plan gives lump sum grant to such religious schools- gurukuls, gumbas and madrasas. The donors' money has been distributing through a directives issued by department od education under government of Nepal as the officials informed me. In addition to this, one "rahat quota teacher" (relief quota) also has been provided the schools including registered gurukul school as well.

Many non-Hindu authors have been criticized by Hindu authors for provocation of the reality. Yogi Ramacharaka (2005) takes such acts as bias and prejudice:

Many of the English attempts to interpret the Hindu philosophies have been made by men who have lived in India as Christian missionaries, and whose duty is to discredit the native beliefs in the minds of the Hindu people in hope of winning them over to the creed and belief of the missionaries, it will be seen how prone to error such attempt must be. (p. 7)

The UN publication put women and Sudra in a same basket seems lack of understanding on separate issues of caste and class or group. Today's Casteism also has been moving to modernity as Jodkha says, "Caste appeared like a 'natural' system of hierarchy, which was to disappear 'naturally', with the process of evolution and modernization" (p. 141). Arole (1998), however, at present could have seen if she was still alive that women and Dalits have been studying Veda and this is also open for non-Hindus.

Experiencing four yugs- Satya, Treta, dwaper and kali; evolution of Puranas aselaboration of Veda, facing external attacks and internal reformist movement, political and technological changes and legal changes the Veda based societies of India and Nepal have made inclusion process for public places and institutions. Recently, 


\section{2| Rajendra Raj Timilsina}

Constitution of Nepal (2015) has guaranteed system of proportional inclusion so that every public organization should recruit human resources on the basis of caste based reservation. Now, Sanskrit university and other such organizations also should appoint its professor of Veda and other Vedic subjects from women, Janajati and Dalit quotas as well. The country should prepare such type of candidates through education and the gurukuls of both Sanatani and Arya Samjee will obviously contribute in producing required human resources. This will abolish the misinterpretation of caste system and help create equal and equitable society making it free from all kinds of superstitions and social malpractices.

\section{Conclusion}

Such status problemetized the issue for this paper as whether there is discrimination to female as sudra in Nepal? The paper explores recent development on access of female to Vedic education. Thinkers and swamis prescribe equal treatment to all. However, social psychology, security and environment have not been able to apply the prescriptions. Men themselves have not been able to study Veda, how the women can? This is the reality. There are vast insecurity for women around the world as we find data of a rape is reported in every 22 minutes only in India (http://www.bbc.com/news/world-asiaindia-37034444). Neither discrimination, nor treating as Sudra, such contextual ontology and global result of conflicts, wars for power and property and physical development in the name of development than the charecterological thinking. Education was charity in Vedic time whereas now it is as a commodity. Now, donors' money has been using to teach all class, caste and cultures through SSRP. Such support has been contributing to the notion of Neo-Sanskritization. There is no discrimination among gender, caste and ethnicity in modern gurukuls and Ashrams. The Vedic gurus, analysts and Vedic interpreters do not restrict such constitutional fundamental rights in public organizations. The indiscriminative Vedic philosophy is inthe-offing to apply as it had been practiced in the Vedic era. Peace, harmony and morality has been felt as a demand of the time because private education sector also incorporating Sanskrit subject (https:// thehimalayantimes.com/kathmandu/private-school-launchessanskrit-class/) as several English speaking zones becoming Sanskrit learning zone as well. Somehow, the zone might introduce 
on gurukuls and girls' access to Veda.

Note: The author does not have other intention while using words Dalits and Sudra. It is for academic purpose. Inconvenience is regretted. Sudra does not carry the meaning of the word Dalit. It was later twisted. Such concept and practice should be reformed and corrected as per the time to make the religion acceptable to all. My argument is that choice of works and name was given accordingly.

\section{Reference}

Adhikari, S. R. (2014). Gender construction in Vedic period. Unpublished $\mathrm{PhD}$ thesis submitted to Tribhuvan University, Kathmandu, Nepal.

Arole, M. (1998). Religion and rights of children and women in South Asia. Kathmandu: UNICEF Regional Office for South Asia.

Bhattarai, K. P. (2016). A context of face to face with Vishuddha Dev. In Voice of Character. Kavre: Hamsada Yoga Ashram

Baidya, T. R. (2001). Devaladevi, the de facto ruler of Nepal. Voice of History, XVI (2), 12-18.

Bihar Prabha. (2016). 700 school girls chant Vedic hymns. August 16, 2016. Retrieved- www.news. biharprabha.com/2016/08/700-school-girls-chantvedic-hymns/

BoP (Bureau of Publication, College of Education) (1956). Education in Nepal: A report of the Nepal national educational planning commission. Kathmandu: Author.

CBS (Central Bureau of Statistics). (2012). National population and housing census 2011: National report. Kathmandu: Author.

CERID (Research Centre for Educational Innovation and Development), (2007). Education in Gumbas, Vihars and Gurukuls in Nepal: Linking with mainstream education. Kathmandu: Author.

Chopra, R. (2015). Sanskrit panel wants labs to test power of Vedic rituals. Indian Express, December 26. Retrieved- http://indianexpress.com/article/india/ india-others/sanskrit-panel-wants-labs-to-test- 


\section{4| Rajendra Raj Timilsina}

power-of-vedic-rituals/

Dayananda Saraswati (2008). Satyartha Prakash (69 $9^{\text {th }}$ edition).Delhi: Arsha Sahitya Prachar Trust.

Government of Nepal (2008). School Sector Reform Plan. Kathmandu: Author.

Grover, V. (2015). Svādhyāya: the vedic mool mantra of education forgotten by indians and paying the price heavily. International Journal of Advanced Research in Management and Social Sciences, 4, (12), 112-123.

Jodkha, S. S. (2012). Caste. Delhi: Oxford University Press. Kaundinnyanh, A. (2007). Women's rights in Vedic Dharmashastra and property (In Nepali). Kathmandu: SajhaPrakashan.

Kaundinnyanah, S. R. Acharya (2005).Vedic Astrology (In Sanskrit- 'Vedangajyotisham'). Varanasi: Chaukhamba Vidyabhavan.

Kaundinnyanah.S.R.Acharya(2009).Sandhyopasanpadhati (In Nepali and Sanskrit). Kathmandu: Ratna Pustak Bhandar.

Kharty, P. K. (2060 B. S.). Religious thoughts and social structure of Nepal. (In Nepali). Kathmandu: M. K. Publishers and Distributers.

Leaman, O. (2004). Eastern philosophy: Key readings. (First Indian Edition): London and New York: Routledge.

Mani, V. (1975). Puranic encyclopedia. Delhi: Motilal Banarasi Das Publishers Private Limited.

Mishra, B. (2003). Vedic method of education. Ujjain: Maharshi Sandipani Rastriya Veda Vigyan Pratisthan.

Michaels, A. (2004). Hinduism: Past and present. New

Delhi: Orient Longman.

Musalgaonker, G. S. (2004). Shaberbhashyam. Varanasi: Chaukhamba Sanskrit Series Office.

Neupane, Y. M. (2002) SarbarthaYogavani. (3 ${ }^{\text {rd }}$ Edition). Kathmandu: Baikalpik Samuha.

Parajuli, M. N. (2013). Valuing people's learning and literacies. Journal of Education and Research, 3 (1), 1-5.

Pokhrel, P. (2012). Women contribution to gurukul 
education. In Gurukul Sandesh, 3, 44-45. Kathmandu: Department of Education.

Swami Prapannyacharya (2013). Milkeka Jhilka (Ignored fire crackers). Panchthar: Kirateshwor Prakashan.

Swami Vishuddha Dev (2059 B. S.). Characterology. Kavre: Hansada Yoga Asharam.

Timilsina R. R. (2013). Neo-Sanskritization for inclusive development through education. In proceeding of fifth SASON international conference. Kathmandu: Sociological/Anthropological Society, Nepal.

Timilsina, R. R. (2015). Sandhyopasan: The Hindu ritual as a foundation of Vedic education. Dahulagiri Journal of Sociology and Anthropology, 9, 53-88.

Weinberg, M. (2013). Revising history in language policy: The case of medium of instruction in Nepal. Working Papers in Educational Linguistics, 28(1), 61-80. Retrieved: www.gse.upenn.edu/wpel

Willis, K. (2005). Theories and practices of development:

Routledge perspectives on development. New York: Routledge. (pp. 29 \& 193)

Yogi Ramacharaka (2005). The philosophies and religion of India. Mumbai: Wilco Publishing House.

Timilsina, Rajendra Raj is a $\mathrm{PhD}$ scholar at Kathmandu University School of Education. Vedic knowledge and education in Nepal is his epistemic area. He served as visiting faculty at Kathmandu University. Professionally, he is a television presenter and senior journalist (Senior News Editor) at Nepal Television (NTV) Corporation. He was founding managing editor of "Telepatrika", a Bi-annual journal of NTV, Editor of Television Journal of Nepal and Associate Editor of "Saadhana" digest. He has published various articles on socio-economic issues in different news magazines. Mr. Timilsina became a first journalist who served as investigation officer at Commission for the Investigation of Abuse of Authority (CIAA). He has been presented papers in national and international symposiums on current issues.

Email: rajendratimilsina@gmail.com 